\title{
Effects of dose and adaptation time of ginger root (Zingiber officinale) on rumen fermentation
}

\author{
T.-T. Zhang, Z.-B. Yang'1, W.-R. Yang, S.-Z. Jiang and G.-G. Zhang
}

Shandong Agricultural University, Department of Animal Science and Technology

Daizong Road 61, Taian 271018, Shandong, P.R. China

(Received 24 February 2011; revised version 5 June 2011; accepted 11 August 2011)

\begin{abstract}
The present study evaluated the effects of different doses and different adaptation time of ginger powder on rumen fermentation in vivo. In Experiment 1, four sheep were used in a 4 x 4 Latin square design to evaluate the effects of three concentrations $(5,10$, and $20 \mathrm{~g} / \mathrm{kg}$ ) of ginger powder on rumen fermentation. Total volatile fatty acid (VFA) concentration was decreased $(\mathrm{P}<0.05)$, but the fatty acid compositions, acetate-to-propionate ratio, $\mathrm{pH}$, and ammonia- $\mathrm{N}$ concentration were unchanged by the addition of ginger powder. In Experiment 2, eight sheep were used to study the long-term adaptation of ginger powder on rumen fermentation. The addition of ginger powder decreased $(\mathrm{P}<0.05)$ the total VFA concentration from days 5 to 20 , but these differences disappeared thereafter. Other rumen fermentation parameters were unchanged when ginger powder was added. Therefore, data from short-term in vitro fermentation studies may lead to erroneous conclusions and should be interpreted with caution.
\end{abstract}

KEY WORDS: ginger powder, ruminal fermentation

\section{INTRODUCTION}

Manipulation of rumen microbial ecosystem for enhancing fibrous feed digestibility and reducing methane emission and nitrogen excretion by ruminants to improve their performance are some of the most important goals of animal nutritionists. Plant extracts are good candidates for achieving one or more of these

\footnotetext{
${ }^{1}$ Corresponding author: e-mail: yangzb@sdau.edu.cn
} 
objectives (Teferedegne, 2000). Moreover, natural plant extracts contain secondary metabolites that have shown antimicrobial activity (Cowan, 1999). Some of them have already been tested for their effects on ruminal microbial fermentation, including sarsaponins (Ryan et al., 1997), phenolic compounds (Evans and Martin, 2000) and essential oils (Cardozo et al., 2004; Busquet et al., 2005). However, the effects of plant extracts on rumen fermentation liquor were inconsistent. Hess et al. (2003) reported that total volatile fatty acid (VFA) concentrations were unchanged by the addition of three saponin-rich tropical fruits (Sapindus saponaria, Enterolobium cyclocarpum and Pithecellobium saman), but P. saman decreased ammonia-N concentration of the rumen fluid. Evans and Martin (2000) observed that using $400 \mathrm{mg} / \mathrm{l}$ of thymol (a main component of oregano) decreased total VFA concentration in vitro. Cardozo et al. (2004) observed that some of the effects of plant extracts on rumen microbial fermentation during the adaptation period (1 to $7 \mathrm{~d}$ ) disappeared after $6 \mathrm{~d}$ of incubation, suggesting that rumen microbes can adapt to additives within $6 \mathrm{~d}$ and the data from short-term in vitro studies may lead to erroneous conclusions. Thus, a long-term adaptation study of plant extracts must be conducted. Ginger (Zingiber officinale Roscoe, Zingiberaceae) rhizome (ginger root) is widely used as spice and in practice of traditional Chinese herbal medicine (Masuda et al., 2004; Tapsell et al., 2006). However, limited data are available on the effect of ginger powder on rumen microbial fermentation. The objective of the present study was to evaluate the effects of different doses and different adaptation time of ginger powder on rumen microbial fermentation.

\section{MATERIAL AND METHODS}

\section{Preparation of ginger powder}

Fresh matured ginger roots were provided by Laiwu Farming Bureau (Laiwu, Shandong, China). In brief, ginger slices [dry matter (DM) $>91 \%$ ] were first dried $\left(40^{\circ} \mathrm{C}\right)$ using a mechanical drier $(20226 \mathrm{~A}$, Shanghai Yangguang Laboratory Instruments Co. Ltd., Shanghai, China) and subsequently milled by a disc mill (FFC-15, Shandong Changlin Machinery Group Co. Ltd.) to pass a $300 \mu \mathrm{m}$ screen. The ginger powder used in this study contained, per kg: 920, 123.8, 60.8 and $67.0 \mathrm{~g}$ of DM, crude protein (CP), ether extract and crude ash, respectively, with $3.536 \mathrm{kcal}$ gross energy. The said compositions were analysed in our laboratory in accordance with AOAC (2000) methods 930.15, 990.03, 920.39, and 942.05 using an adiabatic bomb calorimeter (GR2800, Changxing Education Instrumentation Co. Ltd., Hunan, China). The powder also contained 10.38, 1.34 and $0.11 \mathrm{~g}$ of 6-gingerol, 6-shogaol and galanolactone, respectively (Rong et al., 2009). 


\section{Experiment 1}

\section{Animals and treatments}

Four Small Tail Han sheep [male; 10 months old; average body weight (BW), $45 \pm 1.94 \mathrm{~kg}$ ] fitted with a ruminal cannula were used to study the effect of ginger powder on rumen microbial fermentation. During the experimental period the sheep were housed in individual concrete-floored pens of approximately $3 \mathrm{~m} \times 3 \mathrm{~m}$ and had access to fresh water at all time. The dietary treatments were maize-soyabean meal-based diets supplemented with $0,5,10$ and $20 \mathrm{~g} / \mathrm{kg}$ diet of the aforementioned prepared ginger powder (Table 1). The ginger powder was incorporated into the diet by replacing equivalent amounts of wheat bran. All experimental diets contained 50\% ground Chinese wild rye (Aneurolepidium Chinese Kitagawa) and 50\% concentrate mixture (DM basis) formulated to meet nutrient requirements recommended by NRC (1985) at 1.2 times energy requirements for maintenance. Total mixed rations were mixed before feeding them to sheep. All diets were given semi-ad libitum and up to $2.25 \mathrm{~kg} \mathrm{DM} / \mathrm{d}$. During the experimental period, the daily ration was provided in two meals $(50 \%$ each) at 08.00 and $16.00 \mathrm{~h}$.

Table 1. Ingredients and nutrient composition of experimental diets, $\mathrm{g} / \mathrm{kg}$ as fed $\mathrm{d}^{1}$

\begin{tabular}{lrrrr}
\hline \multirow{2}{*}{ Item } & \multirow{2}{*}{ Control } & \multicolumn{3}{c}{ Dietary ginger content, $\mathrm{g} / \mathrm{kg}$} \\
\cline { 3 - 5 } & & 5 & 10 & 20 \\
\hline Ingredients & & & & \\
$\quad$ maize & 325.0 & 325.0 & 325.0 & 325.0 \\
$\quad$ soyabean meal (43\% CP) & 100.0 & 100.0 & 100.0 & 100.0 \\
$\quad$ Chinese wild rye & 500.0 & 500.0 & 500.0 & 500.0 \\
$\quad$ wheat bran & 50.0 & 45.0 & 40.0 & 30.0 \\
$\quad$ ginger powder & - & 5.0 & 10.0 & 20.0 \\
$\quad$ calcium hydrogen phosphate & 10.0 & 10.0 & 10.0 & 10.0 \\
limestone & 5.0 & 5.0 & 5.0 & 5.0 \\
NaCl & 5.0 & 5.0 & 5.0 & 5.0 \\
premix & 5.0 & 5.0 & 5.0 & 5.0 \\
Chemical composition (analysed) & & & & \\
$\quad$ crude protein & 114.4 & 114.2 & 114.1 & 113.9 \\
$\quad$ calcium & 6.8 & 6.8 & 6.8 & 6.8 \\
$\quad$ phosphorus & 4.9 & 4.9 & 4.9 & 4.9 \\
Digestible energy, MJ/kg DM & 11.6 & 11.6 & 11.7 & 11.7 \\
\hline
\end{tabular}

${ }^{1}$ control group was fed with the basal diet. The other treatment diets were supplemented with 5,10 , or $20 \mathrm{~g} / \mathrm{kg}$ diet of ginger powder by replacing equivalent amounts of wheat bran in the basal diet 2 premix provided per kg of complete diet; IU: vit. A 3.300; vit. D 2.000; vit. E 20; mg: S 200; Fe 24; Cu 8; Mn 40; Zn 40; I 0.3; Se 0.2; Co 0.1; calcium pantothenate 30; niacin 25.6 
Experimental design, sample collection and chemical analyses

A 4 x 4 Latin square design experiment was used with $12 \mathrm{~d}$ periods, which included $10 \mathrm{~d}$ of dietary adjustment followed by $2 \mathrm{~d}$ of sampling. On the $11^{\text {th }}$ day of each period, $10 \mathrm{ml}$ of ruminal fluid was collected from each sheep $2 \mathrm{~h}$ after the morning feeding and in 2 consecutive days using an oro-ruminal probe and a vacuum pump. The $\mathrm{pH}$ of the fluid was determined immediately, and samples were collected for the analysis of ruminal ammonia-N and VFA.

The $\mathrm{pH}$ of rumen liquor was determined immediately using a $\mathrm{pH}$ meter (model PB-20, Sartorius, Germany). Ruminal ammonia-N and VFA were determined using the methods described by Hu et al. (2005).

\section{Statistical analyses}

All data were analysed using the GLM procedure of SAS software system (SAS, 1999). Type III sum of squares were used to determine whether treatment effects are significant. Duncan's multiple range tests were used to examine the significance of difference between means. Treatments were evaluated for linear and quadratic effects using polynomial contrasts.

\section{Experiment 2}

\section{Animals and treatments}

Eight Small Tail Han male sheep (16 months old; average BW $52 \pm 2.27 \mathrm{~kg}$ ) fitted with a ruminal cannula were used to study the long-term adaptation of ginger powder on rumen microbial fermentation. Four sheep were randomly assigned to the control treatment (without ginger powder) and four sheep were assigned to the long-term $(30 \mathrm{~d})$ adaptation to ginger powder treatment $(10 \mathrm{~g} / \mathrm{kg}$ diet $)$. The basal diet and feeding procedures were the same as those in Experiment 1 . The sheep were fed at semi-ad libitum feed intake and up to $2.25 \mathrm{~kg} \mathrm{DM} / \mathrm{d}$. During the experimental period, the daily ration was also provided in two meals $(50 \%$ each) at 08.00 and $16.00 \mathrm{~h}$.

\section{Experimental design and sample collection}

At the $1^{\text {st }}, 5^{\text {th }}, 10^{\text {th }}, 15^{\text {th }}, 20^{\text {th }}, 25^{\text {th }}$ and $30^{\text {th }}$ day of the long-term experiment, $10 \mathrm{ml}$ of ruminal fluid was taken $2 \mathrm{~h}$ after the morning feeding to determine $\mathrm{pH}$, ruminal ammonia-N and VFA. 


\section{Chemical analyses}

The $\mathrm{pH}$, ruminal ammonia-N and VFA were determined using the same procedures described in Experiment 1.

\section{Statistical analyses}

All data were analysed using the SAS software system (SAS, 1999). The results were analysed using PROC GLM for repeated measures. The model accounted for the effects of treatments and days, as well as the interaction of treatment with day. The significance of differences among treatments and sampling days was tested using Duncan's multiple range tests. All statements of significance were based on the probability of $\mathrm{P}<0.05$.

\section{RESULTS}

The treatment $\mathrm{x}$ day interactions were not significant for any of the measurements. The main effects are discussed in the following subsections.

\section{Experiment 1}

Total VFA concentration was significantly decreased $(\mathrm{P}<0.05)$, however, the fatty acid composition and the ratio of acetate to propionate were unchanged by the addition of ginger powder. Moreover, a linear tendency $(\mathrm{P}=0.054)$ on the total VFA with increasing concentration of the ginger powder was observed. There was no significant difference in $\mathrm{pH}$ and ammonia-N concentration (Table 2).

Table 2 Effect of ginger powder on rumen fermentation in sheep (Experiment 1)

\begin{tabular}{|c|c|c|c|c|c|c|c|}
\hline \multirow{2}{*}{ Item } & \multirow{2}{*}{ Control } & \multicolumn{3}{|c|}{ Ginger, g/kg } & \multirow{2}{*}{ SEM } & \multicolumn{2}{|c|}{ Effects P } \\
\hline & & 5 & 10 & 20 & & linear & quadratic \\
\hline$\overline{\mathrm{pH}}$ & 5.99 & 6.14 & 6.09 & 6.12 & 0.13 & 0.545 & 0.729 \\
\hline Ammonia-N, mg/l & 120 & 120 & 125 & 134 & 3.7 & 0.264 & 0.537 \\
\hline Total VFA, mmol/1 & $118^{\mathrm{a}}$ & $105^{\mathrm{b}}$ & $103^{\mathrm{b}}$ & $100^{\mathrm{b}}$ & 2.87 & 0.054 & 0.083 \\
\hline Acetate, $\mathrm{mol} / 100 \mathrm{~mol}$ & 73.6 & 72.8 & 73.3 & 73.3 & 0.80 & 0.968 & 0.886 \\
\hline Propionate, $\mathrm{mol} / 100 \mathrm{~mol}$ & 13.9 & 14.9 & 13.9 & 14.5 & 0.81 & 0.765 & 0.956 \\
\hline Butyrate, mol/100 mol & 12.5 & 12.3 & 12.8 & 12.2 & 0.42 & 0.707 & 0.773 \\
\hline Acetate/propionate & 5.31 & 4.94 & 5.28 & 5.09 & 0.49 & 0.781 & 0.948 \\
\hline
\end{tabular}

${ }^{a, b}$ means within a row with different superscripts differ significantly $(\mathrm{P}<0.05)$

\section{Experiment 2}

The addition of ginger powder decreased $(\mathrm{P}<0.05)$ the total VFA concentration from days 5 to 20 , but these differences disappeared thereafter. However, individual 
VFA proportions, acetate-to-propionate ratio, $\mathrm{pH}$, and ammonia- $\mathrm{N}$ concentration were not affected by the addition of ginger powder over the entire feeding period (Table 3).

Table 3. Effect of ginger powder on rumen fermentation in sheep (Experiment 2)

\begin{tabular}{lccc}
\hline Item & \multicolumn{2}{c}{ Treatments } & \multirow{2}{*}{ SEM } \\
\cline { 2 - 3 } Total VFA, mmol/l & control & ginger & \\
Day 1 & & & 1.44 \\
5 & 91.8 & $90.4^{\mathrm{A}}$ & 2.86 \\
10 & $94.2^{\mathrm{y}}$ & $76.3^{\mathrm{Cz}}$ & 2.81 \\
15 & $94.7^{\mathrm{y}}$ & $77.6^{\mathrm{Cz}}$ & 2.92 \\
20 & $89.4^{\mathrm{y}}$ & $76.9^{\mathrm{Cz}}$ & 3.38 \\
25 & $89.2^{\mathrm{y}}$ & $79.7^{\mathrm{BCz}}$ & 2.27 \\
30 & 91.0 & $85.3^{\mathrm{AB}}$ & 2.09 \\
SEM & 89.7 & $85.4^{\mathrm{AB}}$ &
\end{tabular}

Acetate, \%

\begin{tabular}{|c|c|c|c|}
\hline Day 1 & 63.8 & 64.0 & 0.53 \\
\hline 5 & 65.0 & 63.3 & 0.64 \\
\hline 10 & 64.7 & 64.1 & 0.68 \\
\hline 15 & 64.3 & 63.3 & 0.97 \\
\hline 20 & 64.6 & 64.6 & 1.28 \\
\hline 25 & 65.3 & 64.2 & 0.69 \\
\hline 30 & 63.3 & 64.5 & 0.69 \\
\hline SEM & 0.60 & 0.99 & \\
\hline \multicolumn{4}{|c|}{ Propionate, \% } \\
\hline Day 1 & 19.6 & 19.8 & 0.52 \\
\hline 5 & 18.6 & 19.2 & 0.57 \\
\hline 10 & 18.2 & 17.8 & 0.60 \\
\hline 15 & 19.3 & 18.9 & 0.86 \\
\hline 20 & 19.6 & 18.6 & 0.63 \\
\hline 25 & 19 & 19.2 & 0.49 \\
\hline 30 & 19.9 & 19.4 & 0.46 \\
\hline SEM & 0.46 & 0.72 & \\
\hline \multicolumn{4}{|c|}{ Butyrate, \% } \\
\hline Day 1 & 16.6 & 16.2 & 0.34 \\
\hline 5 & 16.4 & 17.5 & 0.65 \\
\hline 10 & 17.1 & 18.1 & 0.48 \\
\hline 15 & 16.4 & 17.8 & 0.43 \\
\hline 20 & 15.8 & 16.8 & 0.98 \\
\hline 25 & 15.7 & 16.6 & 0.47 \\
\hline 30 & 16.8 & 16.1 & 0.53 \\
\hline SEM & 0.48 & 0.67 & \\
\hline
\end{tabular}


Table 3 continued

\begin{tabular}{|c|c|c|c|}
\hline \multirow{2}{*}{ Item } & \multicolumn{2}{|c|}{ Treatments } & \multirow{2}{*}{ SEM } \\
\hline & control & ginger & \\
\hline \multicolumn{4}{|c|}{ Acetate/propionate } \\
\hline Day 1 & 3.27 & 3.25 & 0.10 \\
\hline 5 & 3.51 & 3.32 & 0.12 \\
\hline 10 & 3.58 & 3.63 & 0.16 \\
\hline 15 & 3.34 & 3.41 & 0.18 \\
\hline 20 & 3.30 & 3.52 & 0.17 \\
\hline 25 & 3.46 & 3.36 & 0.12 \\
\hline 30 & 3.20 & 3.33 & 0.11 \\
\hline SEM & 0.11 & 0.17 & \\
\hline \multicolumn{4}{|l|}{$p H$} \\
\hline Day 1 & 6.14 & 6.24 & 0.08 \\
\hline 5 & 6.17 & 6.14 & 0.09 \\
\hline 10 & 6.39 & 6.15 & 0.10 \\
\hline 15 & 6.14 & 6.17 & 0.07 \\
\hline 20 & 6.14 & 6.21 & 0.05 \\
\hline 25 & 6.22 & 6.37 & 0.07 \\
\hline 30 & 6.16 & 6.24 & 0.08 \\
\hline SEM & 0.07 & 0.09 & \\
\hline \multicolumn{4}{|c|}{ Ammonia- $N$, mg/l } \\
\hline Day 1 & 168 & 168 & 4.33 \\
\hline 5 & 170 & 174 & 8.00 \\
\hline 10 & 168 & 176 & 4.70 \\
\hline 15 & 163 & 173 & 5.81 \\
\hline 20 & 163 & 179 & 12.0 \\
\hline 25 & 162 & 168 & 7.08 \\
\hline 30 & 164 & 172 & 7.40 \\
\hline SEM & 8.41 & 6.37 & \\
\hline
\end{tabular}

${ }^{\mathrm{A}-\mathrm{C}}$ means within a column with different superscripts differ significantly $(\mathrm{P}<0.05)$

$y, z$ means within a row with different superscripts differ significantly $(\mathrm{P}<0.05)$

\section{DISCUSSION}

Natural plant extracts have antimicrobial properties that may provide an alternative to ruminal modifiers because of their ability to improve energy or protein use in the rumen (Kamel, 2001). However, there is very limited information on the effects of ginger powder on ruminal microbial fermentation. VFAs are end products of rumen microbial fermentation and represent the main supply of metabolizable energy for ruminants (Van Soest, 1982). In the present study, total VFA concentration was decreased by the addition of ginger powder, suggesting that the doses of ginger powder used modify diet fermentability. The use of ginger powder with antimicrobial activity would likely decrease microbial 
activity and diet fermentability. Mascolo et al. (1989) reported that hydroethanolic ginger extract exhibited potency of antibacterial activity against Gram-positive and Gram-negative bacteria. Many other plant extracts and secondary plant metabolites at the highest dose decreased the total VFA concentration as a result of the antimicrobial effects (Busquet et al., 2006; Castillejos et al., 2006; Santoso et al., 2007). However, some other studies found that water, methanol and ethanol extracts of ginger had no effect on the total VFA in vitro (Patra et al., 2006, 2010). This variability is partly explained by the difference between in vitro and in vivo studies, and the preparation of ginger. The individual VFA proportions and acetate-to-propionate ratio were not affected by the addition of ginger powder, in agreement with previous in vitro studies (Patra et al., 2010). Ammonia in the rumen is produced from the degradation of dietary and microbial protein (Leng and Nolan, 1984). Hu et al. (2005) reported that ammonia-N concentration was decreased and the microbial crude protein (MCP) yield increased by the addition of tea saponin, suggesting that tea saponin can improve dietary $\mathrm{N}$ utilization and increase MCP flow to the intestine. However, there is limited information on the effect of ginger powder on ammonia- $\mathrm{N}$ concentration in the rumen. In the present study, there was no significant difference in ammonia- $\mathrm{N}$ concentration. By contrast, Sallam et al. (2009) reported that G0.5 (methanol extract of ginger at the $0.5 \mathrm{ml} / 75 \mathrm{ml}$ buffered rumen fluid) decreased the ammonia-N concentration, whereas G1 and G1.5 increased it in the in vitro study. This result may be due to the differences between in vitro and in vivo studies.

In Experiment 2, the addition of ginger powder decreased the total VFA concentration from days 5 to 20 , but these differences disappeared thereafter. These results suggest that, although ginger powder had a short-term effect on ruminal microbial fermentation, ruminal microbes can adapt after 20 days and build up a tolerance to it. Similar to the results in Experiment 1, the addition of ginger powder had little effect on individual VFA proportions, acetate-topropionate ratio, $\mathrm{pH}$, and ammonia- $\mathrm{N}$ concentration, indicating that ginger powder did not affect these indices in both the short-term and the long-term adaptation experiment. In a previous in vitro study of the dual-flow continuous culture system, Cardozo et al. (2004) observed that some of the effects of plant extracts on rumen microbial fermentation during the adaptation period (days 1 to 7) disappeared after $7 \mathrm{~d}$ of incubation, suggesting that rumen microbes can adapt to additives within $7 \mathrm{~d}$. By comparison, in the same dual-flow continuous culture system, Busquet et al. (2005) observed that the changes in cinnamaldehyde and garlic oil in fermentation were observed within $48 \mathrm{~h}$ and remained unchanged until the end of the experiment, indicating that $2 \mathrm{~d}$ are sufficient for the adaptation of rumen microflora to the fermentation conditions and to the presence of feed additives. Molero et al. (2004) reported that BEO (a specific blend of essential oils) only reduced protein degradation of soyabean and sunflower meals when the 
adaptation period was extended to $28 \mathrm{~d}$, suggesting that the adaptation period may be important in revealing the effects of BEO on protein degradation. Wallace et al. (2003) observed the same result. Wang et al. (1998) reported that yucca extract decreased ammonia concentration only from days 5 to 11 and thereafter the change disappeared; however, the total VFA concentrations and the molar proportions of the acetate, propionate and butyrate were not affected in the rumen simulation technique. Castillejos et al. (2007) reported that the changes in VFA concentration and proportions by BEO only required a short adaptation time, longer than $24 \mathrm{~h}$ but lower than $6 \mathrm{~d}$. On the other hand, $\mathrm{N}$ metabolism required an adaptation time of up to $4 \mathrm{wk}$. These studies provide compelling evidence that microbial populations can adapt to additives over time, thereby presenting a challenge for the application of this feed additive technology. More importantly, these findings suggest that results from short-term fermentation studies should be interpreted with caution.

Differences in the data of every index between Experiments 1 and 2 were observed. The difference in the age of the sheep in the two studies was one cause of the difference in the data. In addition, the seasons during which the two experiments were conducted were different. Experiment 1 was conducted in summer, during which the average temperature is approximately $25^{\circ} \mathrm{C}$. By contrast, Experiment 2 was conducted in winter, when the average temperature is approximately $0^{\circ} \mathrm{C}$. A follow-up study will be conducted to investigate the differences in the data further.

\section{CONCLUSIONS}

Total volatile fatty acids (VFA) concentration in the rumen fluid of sheep was decreased by the addition of ginger powder in the first experiment. When the adaptation period was extended to $30 \mathrm{~d}$, the addition of ginger powder decreased the total VFA concentration from days 5 to 20, but these differences disappeared thereafter probably because of the adaptation of the bacteria to these additives. The results of both experiments suggest that data from short-term in vitro studies may lead to erroneous conclusions. The addition of ginger powder can shift the microbial fermentation in the rumen by inhibiting the total VFA concentration.

\section{REFERENCES}

AOAC, 2000. Association of Official Analytical Chemists, Official Methods of Analysis. $17^{\text {th }}$ Edition. Gaithersburg, MD

Busquet M., Calsamiglia S., Ferret A., Cardozo P.W., Kamel C., 2005. Effects of cinnamaldehyde and garlic oil on rumen microbial fermentation in a dual flow continuous culture. J. Dairy Sci. $88,2508-2516$ 
Busquet M., Calsamiglia S., Ferret A., Kamel C., 2006. Plant extracts affect in vitro rumen microbial fermentation. J. Dairy Sci. 89, 761-771

Cardozo P. W., Calsamiglia S., Ferret A., Kamel C., 2004. Effects of natural plant extracts on ruminal protein degradation and fermentation profiles in continuous culture. J. Anim. Sci. 82, 3230-3236

Castillejos L., Calsamiglia S., Ferret A., 2006. Effect of essential oils active compounds on rumen microbial fermentation and nutrient flow in in vitro systems. J. Dairy. Sci. 89, 2649-2658

Castillejos L., Calsamiglia S., Ferret A., Losa R., 2007. Effect of dose and adaptation time of a specific blend of essential oil compounds on rumen fermentation. Anim. Feed Sci. Tech. 132, 186-201

Cowan M.M., 1999. Plant products as antimicrobial agents. Clin. Microbiol. Rev. 12, 564-582

Evans J. D., Martin S. A., 2000. Effect of thymol on ruminal microorganisms. Curr. Microbiol. 41, 336-340

Hess H.D., Kreuzer M., Díaz T.E., Lascano C.E., Carulla J.E., Soliva C.R., Machmüller A., 2003. Saponin rich tropical fruits affect fermentation and methanogensesis in faunated and defaunated rumen fluid. Anim. Feed Sci. Tech. 109, 79-94

Hu W.L., Liu J.X., Ye J.A., Wu Y.M., Guo Y.Q., 2005. Effect of tea saponin on rumen fermentation in vitro. Anim. Feed Sci. Tech. 120, 333-339

Kamel C., 2001. Tracing modes of action and roles of plant extracts in non-ruminants. In: P.C. Garnsworthy, J. Wiseman (Editors). Recent Advances in Animal Nutrition. Nottingham University Press, Nottingham (UK)

Leng R.A., Nolan J.V., 1984. Nitrogen metabolism in the rumen. J. Dairy Sci. 67, 1072-1089

Mascolo N., Jain R., Jain S.C., Capasso F., 1989. Ethnopharmacologic investigation of ginger (Zingiber officinale). J. Ethnopharmacol. 27, 129-140

Masuda Y., Kikuzaki H., Hisamoto M., Nakatani N., 2004. Antioxidant properties of gingerol related compounds from ginger. Biofactors 21, 293-296

Molero R., Ibars M., Calsamiglia S., Ferret A., Losa R., 2004. Effect of a specific blend of essential oil compounds on dry matter and crude protein degradability in heifers fed diets with different forage to concentrate rations. Anim. Feed Sci. Tech. 114, 91-104

NRC, 1995. Nutrient Requirements of Sheep. $6^{\text {th }}$ Edition. National Academy Press. Washington, $\mathrm{DC}$

Patra A.K., Kamra D.N., Agarwal Neeta, 2006. Effect of spices on rumen fermentation, methanogenesis and protozoa counts in in vitro gas production test. Int. Congress Ser. 1293, 176-179

Patra A.K., Kamra D.N., Agarwal Neeta, 2010. Effect of extracts of spices on rumen methanogenesis, enzyme activities and fermentation of feeds in vitro. J. Sci. Food Agr. 90, 511-520

Rong X., Peng G., Suzuki T., Yang Q., Yamahara J., Li Y., 2009. A 35-day gavage safety assessment of giner in rats. Regul. Toxicol. Pharmacol. 54, 118-123

Ryan J.P., Quinn T., Leek B.L., 1997. Comparison of effects of Yucca schidigera plant extract (DeOdorize) and Saccharomyces cerevisiae yeast culture (Yea-Sacc 1026) on pH, short chain fatty acids (SCFA) and ammonium, during fermentation of hay by sheep's ruminal fluid in vitro. J. Dairy Sci. 81, 3222-3230

Sallam S.M.A., Bueno I.C.S., Brigide P., Godoy P.B., Vitti D.M.S.S., Abdalla A.L., 2009. Investigation of potential new opportunities for plant extracts on rumen microbial fermentation in vitro. Options Méditerranéennes 85, 255-260

Santoso B., Kilmaskossu A., Sambodo P., 2007. Effects of saponin from Biophytum petersianum Klotzsch on ruminal fermentation, microbial protein synthesis and nitrogen utilization in goats. Anim. Feed Sci. Tech. 137, 58-68

SAS, 1999. Version 8.0, SAS Institute Inc. Cary, NC 
Tapsell L.C., Hemphill I., Cobiac L. et al., 2006. Health benefits of herbs and spices: The past, the present, the future. Med. J. Aust. 185, 4-24

Teferedegne B., 2000. New perspectives on the use of tropical plants to improve ruminant nutrition. Proc. Nutr. Soc. 59, 209-214

Van Soest P.J., 1982. Nutritional Ecology of the Ruminant. Comstock, Cornell University Press. Ithaca, NY

Wallace R.J., McEwan N.R., McIntosh F.M., Newbold C.J., 2003. Natural products for manipulation of fermentation in ruminats. In: Proceedings of the $50^{\text {th }}$ Maryland Nutrition Conference for Feed Manufactures and $1^{\text {st }}$ Mid-Atlantic Conference. University of Maryland. Timonium, MA, pp. 116-125

Wang Y., McAllister T.A., Newbold C.J., Rode L.M., Cheeke P.R., Cheng K.-J., 1998. Effect of Yucca schidigera extract on fermentation and degradation of steroidal saponins in the rumen simulation technique (RUSITEC). Anim. Feed Sci. Tech. 74, 143-153 